\title{
Development of Al-B-C Master Alloy Under External Fields
}

\author{
UTSAVI JOSHI, SREEKUMAR VADAKKEMADAM, DMITRY G. ESKIN, \\ and HARI BABU NADENDLA
}

\begin{abstract}
This study investigates the application of external fields in the development of an Al-B-C alloy, with the aim of synthesizing in situ $\mathrm{Al}_{3} \mathrm{BC}$ particles. A combination of ultrasonic cavitation and distributive mixing was applied for uniform dispersion of insoluble graphite particles in the $\mathrm{Al}$ melt, improving their wettability and its subsequent incorporation into the Al matrix. Lower operating temperatures facilitated the reduction in the amount of large clusters of reaction phases, with $\mathrm{Al}_{3} \mathrm{BC}$ being identified as the main phase in XRD analysis. The distribution of $\mathrm{Al}_{3} \mathrm{BC}$ particles was quantitatively evaluated. Grain refinement experiments reveal that Al-B-C alloy can act as a master alloy for $\mathrm{Al}-4 \mathrm{Cu}$ and $\mathrm{AZ91D}$ alloys, with average grain size reduction around 50 pct each at $1 \mathrm{wt}$ pctAl-1.5B-2C additions.
\end{abstract}

DOI: $10.1007 / \mathrm{s} 11661-015-2926-0$

(C) The Minerals, Metals \& Materials Society and ASM International 2015

\section{INTRODUCTION}

THE increase in demand for lighter and stiffer components, high precision, and dimensional stability in the aerospace and non-aerospace applications have driven the development of aluminum-based metal-matrix composites (MMCs). Lighter Al matrix can be strengthened by the hard ceramic particles such as $\mathrm{SiC}$, $\mathrm{Al}_{2} \mathrm{O}_{3}, \mathrm{TiB}_{2}$, and $\mathrm{B}_{4} \mathrm{C}$ to enhance the mechanical properties. ${ }^{\left[1{ }^{1}\right.}$ ' However, the concerns over achieving homogeneous distribution of particles, wettability, chemical reactions at the interface and porosity could limit the applications of MMCs. More often, dispersive stirring using a mechanical stirrer is used for improving the particle dispersion in the matrix. While larger particles of the range from 20 to $50 \mu \mathrm{m}$ could be successfully dispersed using a mechanical stirring alone, the finer particles of sub-micrometers tend to form large clusters. $^{[2]}$ Recently, ultrasonic cavitation and high shearing techniques were found to be helpful in the deagglomeration and dispersion of fine and nano particles in Al alloys. ${ }^{[3]}$ Several research papers have addressed the wettability issues and have shown better performance of the composites produced through in situ techniques. The in situ particles of $\mathrm{TiB}_{2}, \mathrm{TiC}, \mathrm{Al}_{2} \mathrm{O}_{3}$, and $\mathrm{MgAl}_{2} \mathrm{O}_{4}$ were shown to have close crystallographic matching with $\mathrm{Al}$ that possibly negates the influence of macro-scale wettability issue with A1. ${ }^{[2,4]}$ This research is directed toward in situ synthesis of $\mathrm{Al}_{3} \mathrm{BC}$ phase in an Al-B-C alloy. $\mathrm{Al}_{3} \mathrm{BC}$ has been identified as a promising material of high hardness and toughness as well as of high chemical and thermal stability. ${ }^{[5]}$ It has also been

UTSAVI JOSHI, PhD Student, SREEKUMAR VADAKKEMADAM, Research Fellow, DMITRY G. ESKIN, Professor, and HARI BABU NADENDLA, Senior Lecturer, are with the Brunel Centre for Advanced Solidification Technology, Brunel University London UB8 3PH, U.K. Contact e-mail: utsavi.joshi@gmail.com

Manuscript submitted December 22, 2014.

Article published online April 30, 2015 shown to act as a heterogeneous nucleating agent for primary $\mathrm{Al}$ and $\mathrm{Mg}$ grains. ${ }^{[6,7]}$ The fabrication process of an Al-B-C alloy employed by most of the previous researchers ${ }^{[8-10]}$ was based on high operation temperatures of higher than $1273 \mathrm{~K}\left(>1000{ }^{\circ} \mathrm{C}\right)$ which resulted in a variety of reaction products such as $\mathrm{AlB}_{2}$, $\mathrm{AlB}_{12} \mathrm{C}_{2}, \beta-\mathrm{AlB}_{12}, \mathrm{AlB}_{10}$, and $\mathrm{Al}_{4} \mathrm{C}_{3}$ in addition to the formation of $\mathrm{Al}_{3} \mathrm{BC}$. These reaction products tend to form large, granular clusters that are undesired for producing any castings. ${ }^{[11]}$ It is therefore essential to develop a novel processing technique for this alloy.

The present study adopts a new route of dispersive mixing with ultrasonic cavitation, with the aim of in situ synthesis of $\mathrm{Al}_{3} \mathrm{BC}$ particles in an Al-B-C alloy. If the wettability of graphite particles is forcibly improved through the application of ultrasonic cavitation, the amount of graphite particles transferred into molten aluminum alloy is expected to increase at relatively low temperatures within a certain stirring time period, and the porosities will also be eliminated. Further, the Al-B$\mathrm{C}$ alloy is tested for grain refinement on $\mathrm{Al}$ and $\mathrm{Mg}$ alloys to identify the suitability of a lower $\mathrm{B} / \mathrm{C}$ ratio (0.75) compared to the higher values considered in the grain refinement study by Tian $2014(\mathrm{~B} / \mathrm{C}=4.0)$ and Ma $2010(\mathrm{~B} / \mathrm{C}=1.67)$.

\section{EXPERIMENTAL PROCEDURE}

\section{A. Processing}

The master alloy preparation consists of introducing graphite particulates into an Al-B alloy (purchased from London and Scandinavian Metallurgical Co. Ltd). Al$5 \mathrm{~B}$ alloy was first diluted to obtain $\mathrm{Al}-1.5 \mathrm{~B}$ melt in an electric furnace at a temperature of $1273 \mathrm{~K}\left(900^{\circ} \mathrm{C}\right)$. Commercial $\mathrm{Mg}$ around $40 \mathrm{gm}$ was added to $1100 \mathrm{gm}$ of Al-1.5B melt followed by $1.0 \mathrm{wt}$ pct of graphite $(<20 \mu \mathrm{m})$ addition. Once the melt was cooled to 
$1003 \mathrm{~K}\left(730^{\circ} \mathrm{C}\right)$, then distributive mixing process is followed using a rotating impeller.

The novel process for synthesizing an Al-B-C alloy consisted of two steps:

i. distributive mixing

ii. dispersive mixing with ultrasonic cavitation

\section{B. Distributive Mixing}

The conventional mechanical stirring was used for distributive mixing ${ }^{[12-14]}$ to pre-mix the graphite particles with the Al-B melt. The mixing equipment as shown in Figure 1 consisted of a driving motor to create the torque on the impeller, a lifting mechanism for the rotation drive unit and stirrer assembly, and a transfer tube for introducing the graphite powder into the melt. To ensure a uniform distribution, the impeller was designed to have a $d / D$ ratio equal to 0.40 and a $w /$ $d$ ratio equal to $0.35^{[15]}$ where $D$ is the inner diameter of the crucible, $d$ is the diameter of the impeller, and $\mathrm{w}$ is the width of the impeller. A four-bladed titanium impeller was coated with boron nitride to prevent a reaction with molten aluminum. The graphite particles were transferred slowly into the Al-B melt which was mechanically stirred at 250 to $320 \mathrm{rpm}$. After all the graphite powder was introduced into the liquid Al-B melt, the mixture was reheated to preset melting temperature and then restirred for 2 to 3 minutes at
$280 \mathrm{rpm}$. Again, the mixture was preheated to the preset melting temperature followed by casting in steel molds.

\section{Dispersive Mixing with Ultrasonic Cavitation}

The distributive mixing stage was an important means to incorporate and distribute the graphite particles in Al-B melt. But the degree of mixing in a conventional mechanical stirrer is limited due to a diminishing velocity gradient from center to the wall within the liquid melt. ${ }^{[16]}$ This could result in formation of large agglomerates of graphite particles in the stagnant areas.

The process of dispersive mixing with ultrasonic cavitation innovatively adopts a distributive mixing action together with the task of increased wetting and deagglomeration of graphite particles through the action of pressure produced by cavitation. The set-up for ultrasonic testing comprised a $5-\mathrm{kW}$ ultrasonic generator, a $5-\mathrm{kW}$ magnetostrictive transducer with watercooling system, and a niobium tip (sonotrode). The experiments were performed at 3.4-kW generator power. The melt of Al-1.5B-1C is treated with ultrasound waves for around 2 to $3 \mathrm{~min}$, with temp from $1003 \mathrm{~K}\left(730{ }^{\circ} \mathrm{C}\right)$ until the temp drops to $953 \mathrm{~K}\left(680^{\circ} \mathrm{C}\right)$. The melt is then heated to $1073 \mathrm{~K}\left(800{ }^{\circ} \mathrm{C}\right)$ before casting in a steel mold. Similar processing is followed for A1-1.5B-2C alloy. The schematic representation of the experimental set-up is as shown in Figure 1.

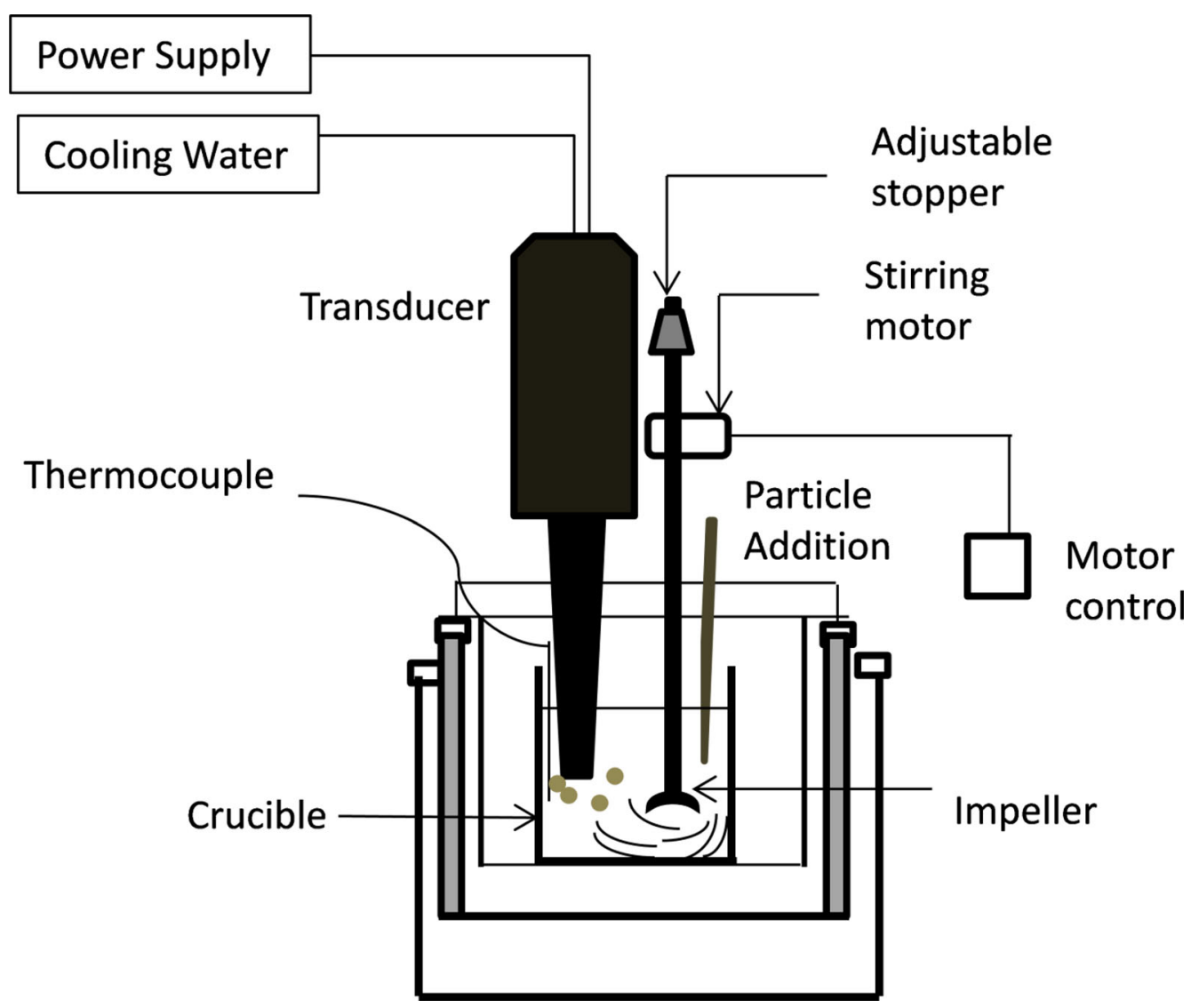

Fig. 1-Schematic diagram of the set-up for distributive mixing and ultrasound cavitation. 
An Al-B-C alloy with $\mathrm{B} / \mathrm{C}<1$ (A1-1.5B-2C) was tested for grain refinement on $\mathrm{Al}-4 \mathrm{Cu}$ alloy and $\mathrm{AZ91D}$ alloy (8.95 pet Al, 0.72 pctZn, 0.19 pctMn, 0.039 pctSi, $<0.001$ pctFe, 0.001 pctCu, $<0.001$ pctNi, 7 ppm Be, and remaining $\mathrm{Mg}$ ). The reference and grain-refined samples of $\mathrm{Al}-4 \mathrm{Cu}$ alloy were obtained in a $523 \mathrm{~K}$ $\left(250{ }^{\circ} \mathrm{C}\right)$ preheated cylindrical steel mold (inner dimensions of $30 \mathrm{~mm}$ diameter and $120 \mathrm{~mm}$ height), while AZ91D samples were obtained at a slower cooling rate in a steel cone mold (with inner dimensions of $80 \mathrm{~mm}$ height and $55 \mathrm{~mm}$ width) preheated to $523 \mathrm{~K}\left(250{ }^{\circ} \mathrm{C}\right)$. The casting temperatures for the reference and grainrefined samples for $\mathrm{Al}-4 \mathrm{Cu}$ was $1025 \mathrm{~K} \pm 2 \mathrm{~K}$ $\left(752{ }^{\circ} \mathrm{C} \pm 2{ }^{\circ} \mathrm{C}\right)$, while that for AZ91D alloy was $958 \mathrm{~K}\left(685^{\circ} \mathrm{C} \pm 2{ }^{\circ} \mathrm{C}\right)$. In case of both the alloys, the Al-1.5B-2C master alloy was left in the melt for $20 \mathrm{~min}$ each before casting in the steel molds. Cover gas of a mixture of sulfur hexafluoride and nitrogen was used during melting and holding of the melt in case of AZ91D, without any flux additions.

\section{Metallographic Characterization}

The Al-B-C alloy samples for microstructural characterization were obtained from different positions along the length of the final castings. Al-4Cu samples considered for optical microscopy (OM) were cylindrical with dimension $30 \mathrm{~mm}$ diameter and $20 \mathrm{~mm}$ height, and the AZ91D cone samples were vertically sectioned. Each of the microstructures were examined under OM, using a Carl Zeiss Axioskop 2 MAT microscope, and scanning electron microscope (SEM), using a Zeiss Supra 35VP FEG microscope equipped with energy dispersive X-ray (EDX), Oxford Instruments Inca. These samples were ground and polished using standard procedures for OM.
The linear intercept method was used to measure the grain size using a Zeiss Axioskop2 MAT optical microscope.

For quantitative analysis of the distribution of reinforcement particles in the Al-B-C alloys (with and without ultrasound), an area count method was used. The area to be studied was divided into 36 contiguous quadrats with a quadrat side of $11.5 \mu \mathrm{m}$ at 100 times magnification. As a general rule of thumb, the quadrat size was taken as approximately twice the size of the mean area per particle. ${ }^{[17]}$ The area count method was performed on 15 different images of each of the alloys prepared with and without ultrasound. To minimize the edge effects, $\mathrm{Al}_{3} \mathrm{BC}$ particles inside and in contact with the left and bottom side of each quadrat were counted and thus, the particles on the quadrat edge were not counted more than once.

\section{RESULTS AND DISCUSSION}

\section{A. Microstructural Analysis of Al-B-C Alloys}

Figure 2 shows the micrograph observed in different regions of the Al-B-C alloy casting. The microstructure of an Al-B-C alloy $(\mathrm{B} / \mathrm{C}<1)$ without ultrasound indicated the presence of agglomerates in situ particles, whereas the alloys $(\mathrm{B} / \mathrm{C}>1$ and $\mathrm{B} / \mathrm{C}<1)$ produced using the ultrasound cavitation were seen to have a uniform distribution of reinforcement.

The XRD image (Figure 3) indicated the presence of $\mathrm{Al}_{3} \mathrm{BC}$ and $\mathrm{Al}_{4} \mathrm{C}_{3}$ particles in $\mathrm{Al}-\mathrm{B}-\mathrm{C}$ alloys produced with and without ultrasound. An increase in the relative intensity of the diffraction peaks for $\mathrm{Al}_{3} \mathrm{BC}$ and $\mathrm{Al}_{4} \mathrm{C}_{3}$ was observed with a rise in carbon contents of the alloys subjected to ultrasound. The amount of undissolved

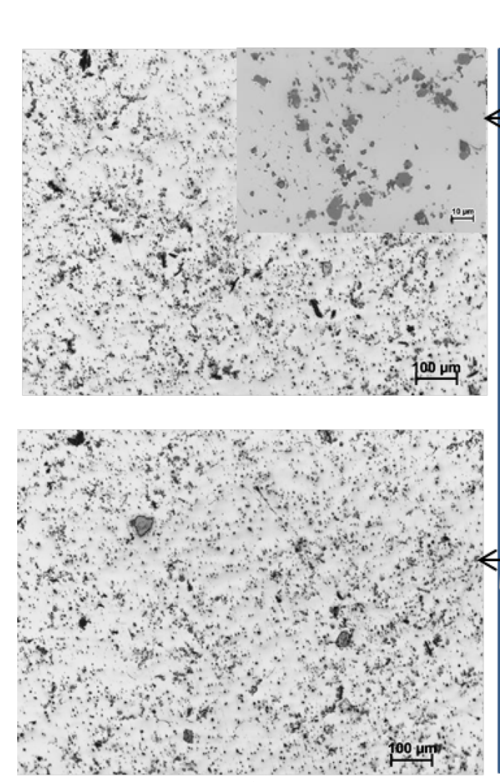

(1)

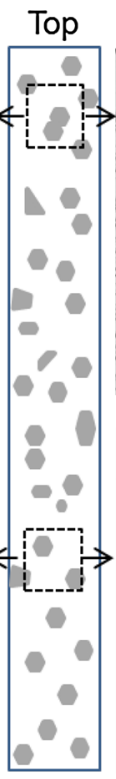

Bottom

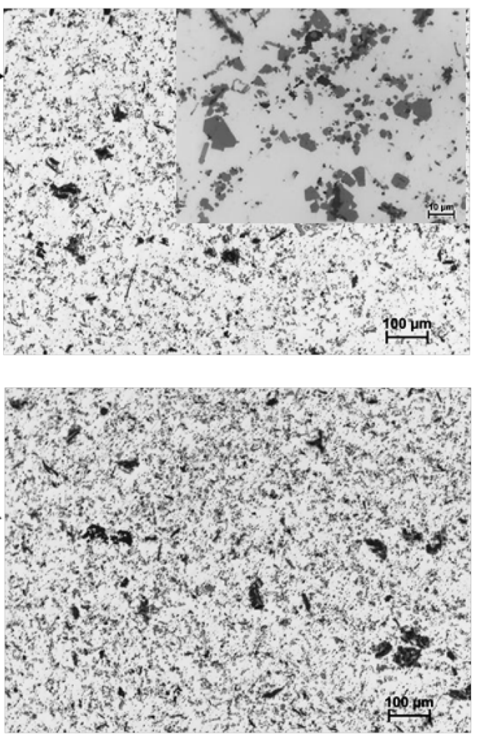

(2)

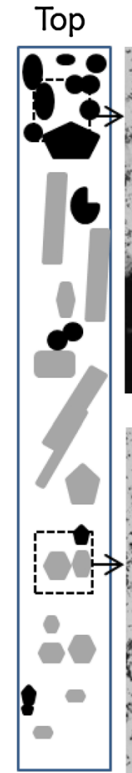

Bottom

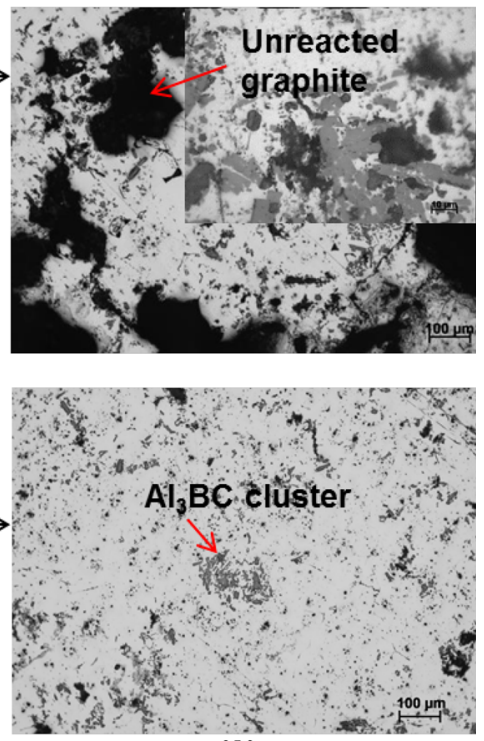

(3)

Fig. 2-Schematic representation of dispersion of reinforced particles with the optical micrographs at different regions of the castings (1) Al1.5B-1C alloy with ultrasound (2) Al-1.5B-2C alloy with ultrasound and (3) Al-1.5B-2C alloy without ultrasound. Inset micrographs are at higher magnification. 
carbon and aluminum in $\mathrm{Al}-1.5 \mathrm{~B}-2 \mathrm{C}$ alloy processed with ultrasound was detected to be lower than that in case of without ultrasound.

The microstructures were further investigated through SEM and EDX analysis (Figure 4). The SEM image shows a cluster of $\mathrm{Al}_{4} \mathrm{C}_{3}$ particles surrounded by $\mathrm{Al}_{3} \mathrm{BC}$ particles. Some of the $\mathrm{Al}_{3} \mathrm{BC}$ particles were also observed in the matrix, with the EDX spectra indicating $\mathrm{Mg}$ peaks in the Al matrix. Gas entrapment was observed in the $\mathrm{Al}_{4} \mathrm{C}_{3}$ cluster as shown in spot 4 (Figure 4). The formation of $\mathrm{Al}_{3} \mathrm{BC}$ phase and its dispersion in the $\mathrm{Al}$ matrix is discussed in the following sections. Although around $3.0 \mathrm{wt}$ pct of $\mathrm{Mg}$ was added in the Al-1.5B-C melt, $\mathrm{MgC}_{2}, \mathrm{Mg}_{2} \mathrm{C}_{3}$, or $\mathrm{MgB}_{2}$ phases were not found from the microstructural observations as it is unfavorable at lower operating temperatures $1100 \mathrm{~K}\left(<827^{\circ} \mathrm{C}\right) .{ }^{[20]}$

During the distributive mixing, the rotation of the stirrer generates a vortex through which the graphite particles could be drawn into the melt. The force provided by stirring the melt with a mechanical stirrer could assist to overcome the surface energy barriers resulting from poor wettability of graphite by $\mathrm{Al}$ alloy.

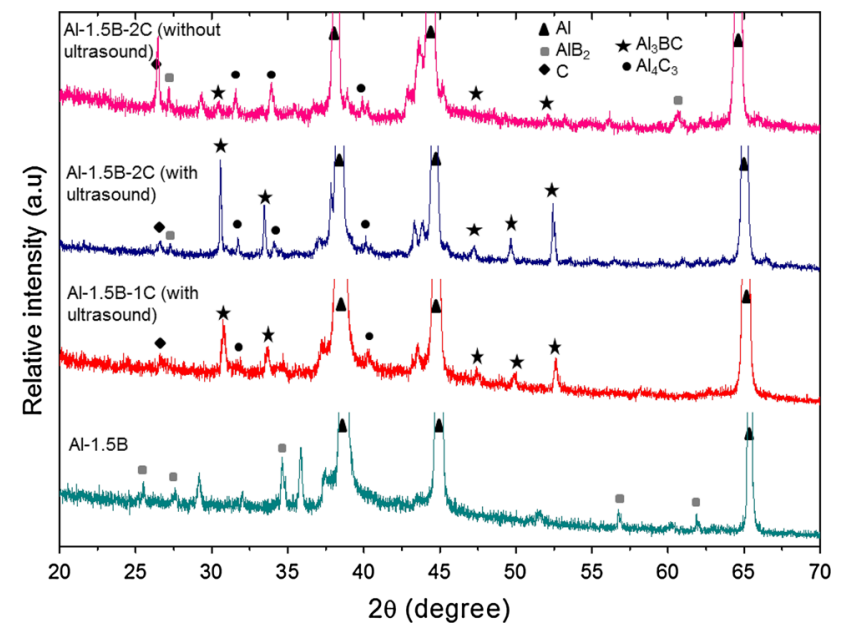

Fig. 3-XRD spectrum of Al-1.5B; Al-1.5B-1C and Al-1.5B-2C with and without ultrasound (few unlabeled peaks in Al-1.5B spectrum belong to potassium salt residue from $\mathrm{KBF}_{4}$ ).
Once the particles were transferred into the liquid, the distribution could be strongly affected by certain flow transitions. The axial flow could cause lifting of particles due to momentum transfer and radial flow could prevent particle settling. A lack of hydrodynamic forces due to a variation in the velocity gradients could result in accumulation of the aggregates in relatively stagnant zones where they survive the shear forces of mixing. ${ }^{[14]}$ These agglomerates are not transported back into the high-shear regions and finally find their way as clusters into the cast structures. Thus mixing is limited for the clusters located away from the impeller, resulting in the characteristic microstructure as shown in Figure 2(3).

A uniform distribution of the $\mathrm{Al}_{3} \mathrm{BC}$ particles as seen in Figure 2(1) and (2) could be attributed to the dispersive mixing with ultrasound cavitation caused by the ultrasonic vibrations. The injection of these ultrasonic fields at high frequency (17 to $25 \mathrm{kHz}$ ) and high amplitude (10 to $40 \mu \mathrm{m}$ null to peak) gives rise to nonlinear effects such as cavitation and acoustic streaming in the liquid $\mathrm{Al}$ melt. A vast number of microscopic Al melt bubbles created due to ultrasonic oscillations will pulsate and implode, giving rise to new bubbles, which is termed as cavitation. ${ }^{[3,18]}$ The resultant pressure and momentum pulses rip the agglomerates apart to assist in distributing the graphite particles in the Al melt. In addition, the acoustic streaming generated at the cavitation region could also assist in the distribution of graphite particles in the $\mathrm{Al}$ matrix.

It is well-known that one of the main factors affecting the efficiency of ultrasonic treatment is the ultrasonic intensity or the extent of acoustic cavitation, where the ultrasonic intensity $\mathrm{I}$ is defined by ${ }^{[19]}$

$$
\mathrm{I}=\frac{1}{2} \rho \mathrm{c}(2 \pi f A)^{2},
$$

where $\rho$ is the liquid density, $c$ the speed of sound in the liquid, $f$ the frequency, and $A$ the amplitude, respectively. High-intensity ultrasonic vibration requires $I \geq 100 \mathrm{~W} \mathrm{~cm}^{-2}$. Moreover, the fully developed cavitation occurs in the molten aluminum alloys when $I \geq 80 \mathrm{~W} \mathrm{~cm}^{-2} \cdot{ }^{[19]}$ In our experiment, it was reasonable to assume $c \approx 1.3 \times 10^{3} \mathrm{~ms}^{-1[19]}$ for molten aluminum alloys, where $\rho=2.385 \mathrm{~g} \mathrm{~cm}^{-3}$. The amplitude of the



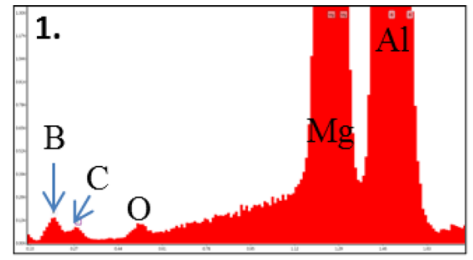

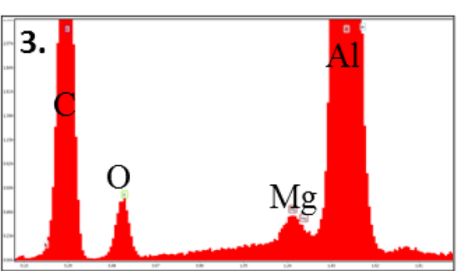

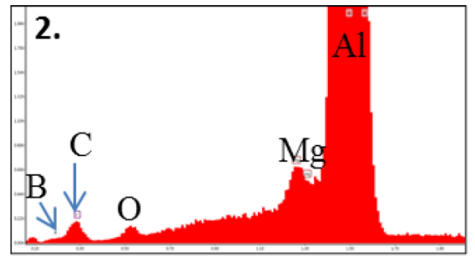

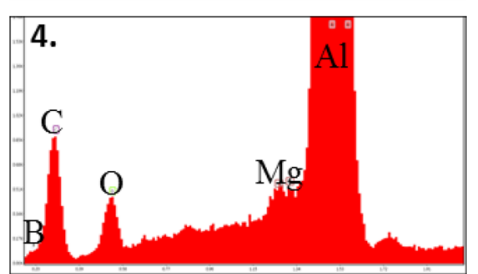

Fig. 4-SEM micrographs and EDS for Al-1.5B-2C subjected to ultrasound. 
ultrasound A was $35 \mu \mathrm{m}$ and the frequency $\mathrm{f}$ was $17.5 \mathrm{kHz}$. Assuming that the surface of the niobium horn was fully wetted by the Al-B-C melt, the intensity of the ultrasonic vibration introduced to the melt was around $2297 \mathrm{~W} \mathrm{~cm}^{-2}$ based on Eq. [1], which was far greater than the cavitation threshold of $80 \mathrm{~W} \mathrm{~cm}^{-2}$. [19] The effect of cavitation produced by ultrasonic vibration in the $\mathrm{Al}$ melt was, therefore, obvious in our work.

Cavitation bubbles nucleate in the Al melt on partly wetted carbon interfaces and gas pockets in the melt. ${ }^{[3,18]}$ The pressure produced by cavitation eases the penetration of liquid melt through the gaps between the graphite particles in the agglomerates. Therefore the ultrasonic cavitation will facilitate the deagglomeration of graphite particles and also improve the wetting through reduction in surface tension at the Al melt/ graphite interfaces.

As shown in Figure 2, the Al-B-C alloys subjected to dispersive mixing with ultrasound had a more homogeneous particle distribution and porosity was reduced. Lower porosity in the sample was attributed to the ultrasonic degassing and could be divided into three stages: (1) nucleation of cavitation bubbles on nuclei and growth of bubbles due to transformation of gases from the surrounding melt to the bubbles, (2) bubble coalescence, and (3) floating and escape of large bubbles through the surface of the melt.

\section{B. Formation of $\mathrm{Al}_{3} B C$ Phase in Al-B-C Alloy}

Previous research ${ }^{[6]}$ suggested that the possible reactions influencing the formation of $\mathrm{Al}_{3} \mathrm{BC}$ and $\mathrm{Al}_{4} \mathrm{C}_{3}$ phases are

$$
4[\mathrm{Al}]+3[\mathrm{C}] \rightarrow \mathrm{Al}_{4} \mathrm{C}_{3}
$$

$$
\mathrm{Al}_{4} \mathrm{C}_{3}+3[\mathrm{~B}]+5[\mathrm{Al}] \rightarrow 3 \mathrm{Al}_{3} \mathrm{BC} .
$$

The Reaction [2] is suggested to occur at the temperature range of $1373 \mathrm{~K}$ to $1573 \mathrm{~K}\left(1100{ }^{\circ} \mathrm{C}\right.$ to $\left.1300{ }^{\circ} \mathrm{C}\right)$. Despite the operating temperatures kept in the range of $973 \mathrm{~K}$ to $1173 \mathrm{~K}\left(700{ }^{\circ} \mathrm{C}\right.$ to $\left.900{ }^{\circ} \mathrm{C}\right), \mathrm{Al}_{4} \mathrm{C}_{3^{-}}$ phase formation could not be avoided. On addition of carbon to the Al-B melt at $973 \mathrm{~K}\left(700{ }^{\circ} \mathrm{C}\right)$ resulted in an increase in viscosity of the melt indicating formation of $\mathrm{Al}_{4} \mathrm{C}_{3}$ phases. The formation of cavitation bubbles due to ultrasonic vibrations in the Al-B melt is expected to have nucleated on poorly wetted surface of carbon particles. The penetration of liquid Al-B melt through agglomerated carbon particles is supported by the pressure created due to the cavitation. Ultrasonic cavitation might have also led to the decrease in surface tension at melt/carbon interfaces, resulting in improved wetting and therefore the formation of $\mathrm{Al}_{4} \mathrm{C}_{3}$ phases. The presence of $\mathrm{Mg}$ in the melt is also expected to contribute to the enhanced wetting of carbon particles. ${ }^{[20]}$

The $\mathrm{B}$ atoms from the Al-1.5B alloy would have dissolved from $\mathrm{AlB}_{2}$ compounds existing in the master alloy and diffused in the surrounding matrix. The solute $\mathrm{B}$ atoms reacted with $\mathrm{Al}_{4} \mathrm{C}_{3}$ phases to give $\mathrm{Al}_{3} \mathrm{BC}$ phases as shown in Reaction [3]. Another possibility is the displacement of $\mathrm{B}$ atoms by $\mathrm{C}$ in $\mathrm{AlB}_{2}$, giving rise to $\mathrm{Al}_{3} \mathrm{BC}$ particles in the liquid Al-based melt.

As shown in Figure 5, distributive mixing with a mechanical stirrer led to segregation of $\mathrm{Al}_{3} \mathrm{BC}$ particles on graphite. The crystals of $\mathrm{Al}_{3} \mathrm{BC}$ grew and eventually it stopped so; some graphite remained unreacted and in form of clusters (stage 4). While in case of dispersive mixing with ultrasonic cavitation, $\mathrm{Al}_{3} \mathrm{BC}$ particles were dispersed under the cavitation effect and new regions of
(4)



Fig. 5-Schematic of $\mathrm{Al}_{3} \mathrm{BC}$ formation and dispersion in $\mathrm{Al}$ (1) reaction of carbon (2) $\mathrm{Al}_{4} \mathrm{C}_{3}$ clustering (3) $\mathrm{Al}_{3} \mathrm{BC}$ formation (4) cluster disintegration. 
graphite particulates became exposed to the $\mathrm{Al}$ melt. This gave rise to more $\mathrm{Al}_{4} \mathrm{C}_{3}$ formation and interaction with $\mathrm{B}$ atoms to form higher number of $\mathrm{Al}_{3} \mathrm{BC}$ particles (stage 4). Therefore, the graphite clusters eventually were consumed in formation of $\mathrm{Al}_{3} \mathrm{BC}$ particles giving rise to a more homogeneous Al-B-C alloy.

\section{C. $\mathrm{Al}_{3} \mathrm{BC}$ Particle Size Distribution}

Figure 6 represents $\mathrm{Al}_{3} \mathrm{BC}$ particle size distribution in Al-B-C alloys, with and without ultrasound. A1-1.5B-2C alloy shows a broader distribution of particle size as compared to that in case of Al-1.5B-1C alloy. For both the alloys (Al-1.5B-1C and Al-1.5B-2C) subjected to ultrasound, the range of $\mathrm{Al}_{3} \mathrm{BC}$ particle size is similar ( 3 to $8 \mu \mathrm{m})$. The Al-1.5B-2C alloy produced without ultrasound was observed to contain larger average particle size, with a broader size distribution. The optical micrographs (Figure 2) confirmed this size distribution analysis. The volume fraction values of $\mathrm{Al}_{3} \mathrm{BC}$ particles in Al-1.5B-1C alloy and Al-1.5B-2C alloys subjected to ultrasound were calculated as 6.1 and 7.7 pct, respectively. The loss in graphite particles due to oxidation and floating could affect the volume distribution of $\mathrm{Al}_{3} \mathrm{BC}$ particles.

It was difficult to calculate the size distribution of $\mathrm{Al}_{4} \mathrm{C}_{3}$ due to its agglomeration tendency toward undissolved graphite particles in the melt.

\section{Quantitative Analysis}

Quantitative methods provide a useful tool for correlating the particle distribution and the properties of the metal-matrix systems. ${ }^{[21]}$ A number of different approaches have been reported on the quantitative study of the reinforcement distribution in a composite such as the Dirichlet tessellation method, ${ }^{[22]}$ the average inter-particle spacing or the mean free path, ${ }^{[23]}$ the nearest and near neighbor distances, ${ }^{[24]}$ the local area fraction, ${ }^{[24]}$ and the radial distribution function. ${ }^{[21]}$

This research has applied the widely accepted quadrat method for quantitatively analysis. In this method, the image to be studied was divided into a grid of square cells and the number of particles, and $N_{\mathrm{q}}$ in each cell was counted. In general, a large number of quadrats containing approximately the same number of particles could be attributed to an ordered particle distribution. On the other hand, a combination of empty quadrats, quadrats with a small number of particles and quadrats with many particles could suggest a clustered particle distribution. A random distribution would be expected to lie in between these two extremes. The major problem of the quadrat method is determining the optimal quadrat size, which is normally considered as a square for simplicity. The nonrandomness of the particles is highly dependent on the size and shape of the sample quadrat. $^{[25]}$

The number of $\mathrm{Al}_{3} \mathrm{BC}$ particles $N_{\mathrm{q}}$ was measured and the degree of asymmetry of a statistical distribution around its mean was quantified by its skewness $\beta$, which is defined by Eq. [4].

$$
\beta=\frac{q}{(q-1)-(q-2)} \sum\left[\frac{N_{q i}-N_{q}^{\text {mean }}}{\sigma}\right]^{3},
$$

where $q$ is the total number of quadrats considered, $N_{\mathrm{qi}}$ is the number of $\mathrm{Al}_{3} \mathrm{BC}$ particles in the ith quadrat $(I=1,2, \ldots, q), N_{q}$ mean is the mean number of $\mathrm{Al}_{3} \mathrm{BC}$ particles per quadrat, and $\sigma$ is the standard deviation of the $N_{q}$ distribution. According to the observations, an increase in $\beta$ indicates an increase in $\mathrm{Al}_{3} \mathrm{BC}$ clustering in an Al-B-C alloy. The skewness value calculated for Al$1.5 \mathrm{~B}-2 \mathrm{C}$ alloy without ultrasonic cavitation was 1.38 , which is a significantly higher value compared to 0.54 under the application of ultrasonic cavitation. This suggested the clustering tendency of graphite particles in the Al alloy melt in the absence of ultrasound.

In mathematical terms, a theoretically random, a spatial and a clustered spatial distribution of particles can be expressed by a Poisson distribution, a binomial distribution, and a negative binomial distribution, respectively. ${ }^{[26]}$

The experimental results from the area count analysis can be compared with the theoretical distribution curves in absolute terms. ${ }^{[21]}$ Figure 7 showed that the distribution for Al-1.5B-2C master alloy without ultrasonic cavitation follows a clustered distribution expressed by a negative binomial curve, whereas the corresponding distribution for the novel dispersive mixing with ultra-
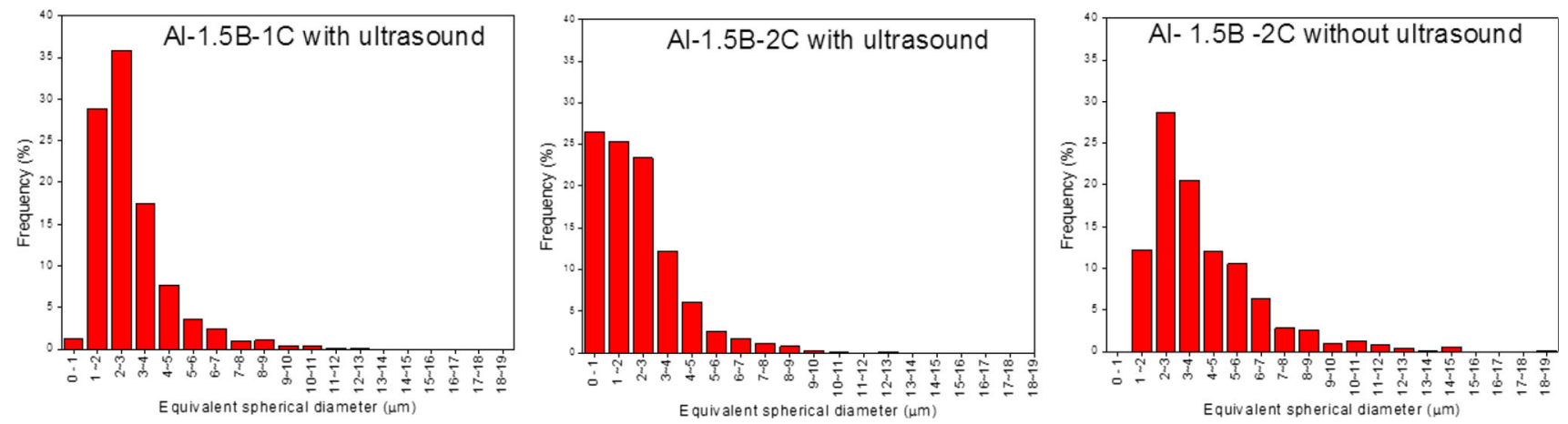

Fig. 6- $\mathrm{Al}_{3} \mathrm{BC}$ particle size distributions. 




Fig. 7-Theoretical distribution curves and experimental results (symbols) from a quadrat analysis of Al-1.5B-2C alloy.
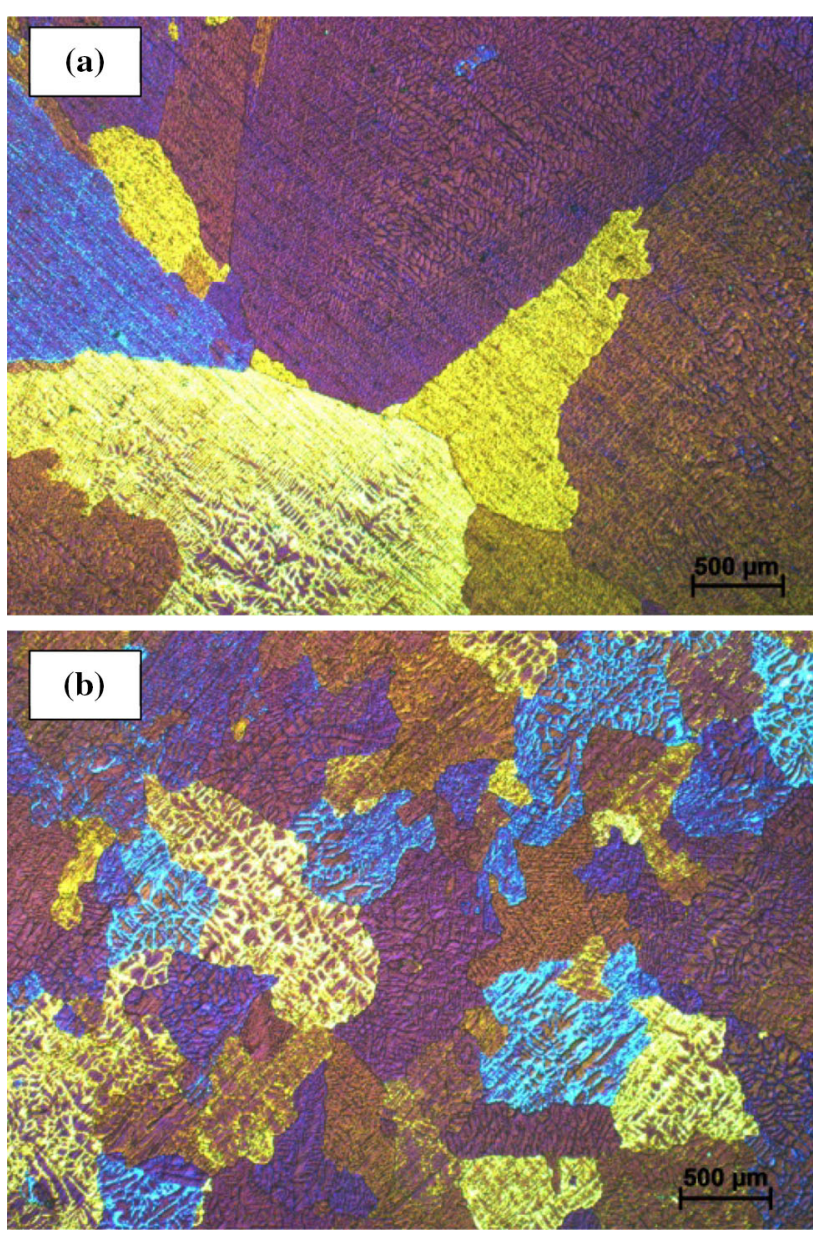

Fig. 8- Optical micrographs of Al-4Cu alloy (a) without Al-1.5B-2C and $(b)$ with 1 wt petAl-1.5B-2C.

sound cavitation was closer to both the Poisson and the binomial distributions compared to the negative binomial distribution, indicating a more uniform distribution.
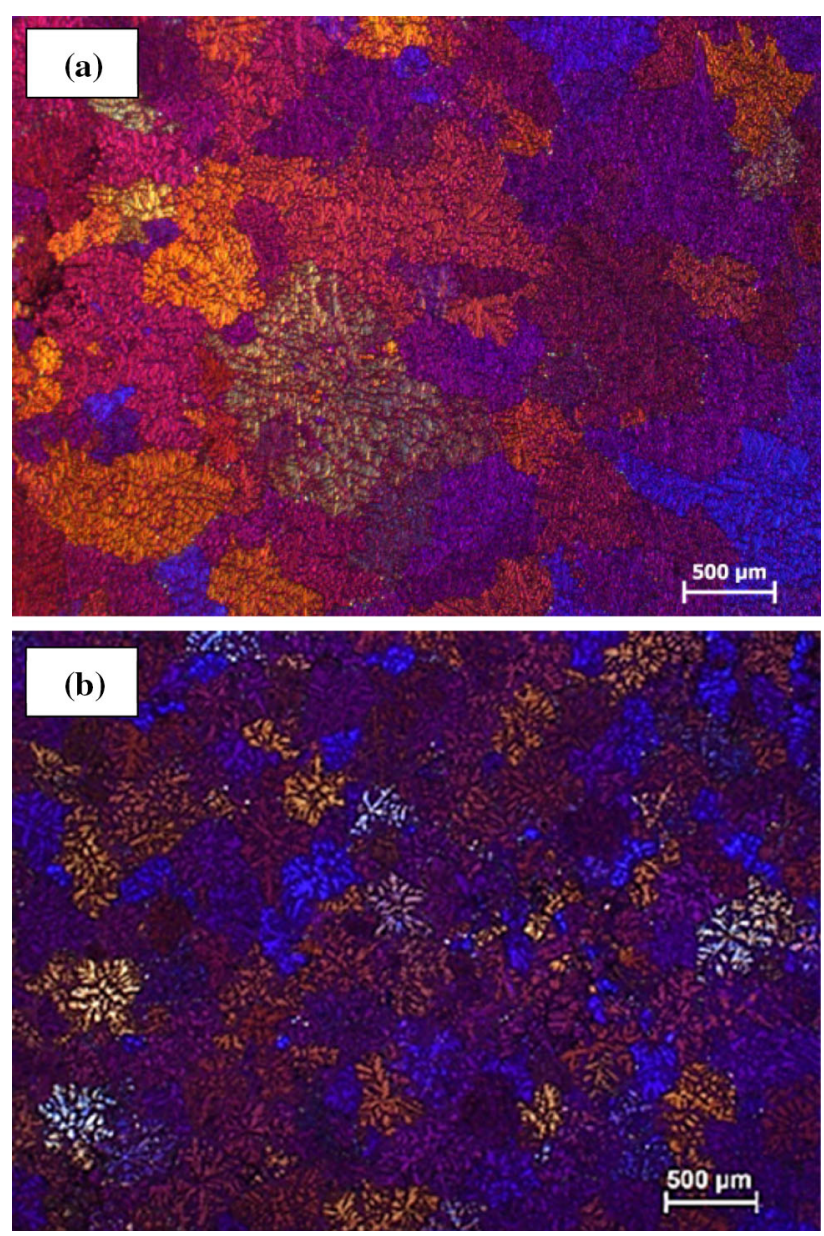

Fig. 9- Optical micrographs of AZ91D alloy (a) without Al-1.5B-2C and $(b)$ with 0.5 wt petAl-1.5B-2C

\section{E. Al-B-C as a Master Alloy}

It is well known that in the $\mathrm{Al}$ alloys containing higher Si content, the potency and efficiency of the commercially used Al-Ti-B master alloy is inhibited due to the poisoning effect. Also, the formation of $\mathrm{Al}_{3} \mathrm{Ti}$ brittle intermetallic could deteriorate the mechanical properties of Al alloys. So, a possible titanium-free alternative in form of Al-B-C master alloy is investigated for grain refinement study. The Al-B-C alloy has several advantages over these commercial master alloys. One of the main advantage is the density of $\mathrm{Al}_{3} \mathrm{BC}\left(2.85 \mathrm{~g} / \mathrm{cm}^{3}\right)$, which is close to that of $\mathrm{Al}\left(2.70 \mathrm{~g} / \mathrm{cm}^{3}\right)$ and considerably lower as compared to $\mathrm{TiB}_{2}\left(4.50 \mathrm{~g} / \mathrm{cm}^{3}\right)$, TiC $\left(4.91 \mathrm{~g} / \mathrm{cm}^{3}\right), \mathrm{Al}_{3} \mathrm{Ti}\left(3.40 \mathrm{~g} / \mathrm{cm}^{3}\right), \mathrm{Al}_{3} \mathrm{Zr}\left(4.10 \mathrm{~g} / \mathrm{cm}^{3}\right)$, and $\mathrm{Al}_{3} \mathrm{Sc}\left(3.03 \mathrm{~g} / \mathrm{cm}^{3}\right)$. The $\mathrm{Al}_{3} \mathrm{BC}$ phase with highelastic modulus $(326 \mathrm{GPa})^{[27]}$ and excellent thermal stability could also act as a strengthening phase for $\mathrm{Al}$ alloys. ${ }^{[12]}$

\section{F. Al-4Cu Alloy}

In the case of $\mathrm{Al}$ alloys, $\mathrm{Al}-\mathrm{Cu}$ system was chosen for grain refinement study of Al-B-C master alloy as it has a 
long freezing range and, therefore, effective grain refinement is essential for producing crack-free castings. The microstructures of as-cast $\mathrm{Al}-4 \mathrm{Cu}$ with and without grain refiner addition are as shown in Figure 8. The average grain size of as-cast $\mathrm{Al}-4 \mathrm{Cu}$ alloy reduces from 1100 to $500 \mu \mathrm{m}$ at $1 \mathrm{wt}$ pet Al-1.5B-2C master alloy additions.

\section{G. AZ91D Alloy}

Despite a significant increase in the number of publications reporting the grain refinement study, there is no availability of reliable and commercially feasible grain refiner for $\mathrm{Al}$ containing $\mathrm{Mg}$ alloys and therefore, AZ91D alloy was chosen for grain refinement study on $\mathrm{Mg}$ alloys.

The microstructures of as-cast AZ91D alloy with and without grain refiner addition are as shown in Figure 9. The average grain size of as-cast AZ91D alloy reduces from 420 to $220 \mu \mathrm{m}$ at $0.5 \mathrm{wt}$ pet Al$1.5 \mathrm{~B}-2 \mathrm{C}$ master alloy additions. The planar disregistries between $\alpha-\mathrm{Mg}$ and $\mathrm{Al}_{3} \mathrm{BC}$ are calculated ${ }^{[6]}$ as 8.8 pct for the crystallographic orientation relationship $(0001)_{\mathrm{Al}_{3} \mathrm{BC}}(0001)_{\mathrm{Mg}}$ and 12.8 pct for $(0001)_{\mathrm{Al}_{3} \mathrm{BC}}$ $(10 \overline{10})_{\mathrm{Mg}}$. So, according to the disregistry model of two-dimensional lattices proposed by Bramfitt, ${ }^{[28]}$ $\mathrm{Al}_{3} \mathrm{BC}$ phase can act as an effective nucleating substrate for $\alpha-\mathrm{Mg}$. The smallest planar disregistry between $\alpha-\mathrm{Mg}$ and $\mathrm{Al}_{4} \mathrm{C}_{3}$ is reported to be $3.35 \mathrm{pct}^{[20]}$ and, therefore, $\mathrm{Al}_{4} \mathrm{C}_{3}$ particles could also act as heterogeneous nuclei for AZ91D alloy.

\section{CONCLUSIONS}

1. Application of external fields in the form of ultrasonic cavitation produced a uniform and homogeneous microstructure for an Al-B-C alloy, consisting mainly of $\mathrm{Al}_{3} \mathrm{BC}$ phases.

2. A1-B-C alloys could be synthesized at lower operating temperatures below $1073 \mathrm{~K}\left(800{ }^{\circ} \mathrm{C}\right)$ to reduce the effect of harmful reaction products that form at higher temperatures.

3. $\mathrm{Al}_{3} \mathrm{BC}$ average particle size was observed to reduce on applying ultrasonic cavitation to Al-B-C alloy as compared to that without ultrasound.

4. A1-1.5B-2C master alloy could efficiently grain refine both $\mathrm{Mg}$ and $\mathrm{Al}$ alloys. Al-4Cu and AZ91D alloys were observed to show an average grain size decrease of around 50 pct each, which indicates the significance of combined effect of $\mathrm{B}$ and $\mathrm{C}$ on the grain refinement of $\mathrm{Al}$ and $\mathrm{Mg}$ alloys.

\section{ACKNOWLEDGMENTS}

The authors acknowledge financial support from the EPSRC. This work was partially supported by the ExoMet Project co-funded by the European Commission's 7th Framework Programme (contract FP7NMP3-LA-2012-280421), by the European Space Agency and by the individual partner organisations.

\section{REFERENCES}

1. T. Clyne and P. Withers: An Introduction to Metal Matrix Composites, Cambridge University Press, Cambridge, 1993.

2. S. Madam, H. Nadendla, D. Eskin, and Z. Fan: Mater. Sci. Eng. $A$, 2015, vol. 628, pp. 30-40.

3. G. Eskin and D. Eskin: Ultrasonic Treatment of Light Alloys Melts, 2nd ed., CRC Press, Boca Raton, 2014.

4. M. Zhang, P. Kelly, M. Easton, and J. Taylor: Acta Mater., 2005, vol. 53 (5), pp. 1427-38.

5. R. Riedel: Adv. Mater., 1994, vol. 6 (7-8), pp. 549-60.

6. G. Ma, G. Han, and X. Liu: J. Alloys Compd., 2010, vol. 491, pp. 165-69.

7. W. Tian, P. Li, and X. Liu: J. Alloys Compd., 2014, vol. 583, pp. 329-34.

8. G. Arslan, F. Kara, and S. Turan: J. Eur. Ceram. Soc., 2013, vol. 23, pp. 1243-55.

9. K. Lee, H. Kim, S. Cho, and H. Kwon: Mater. Sci. Eng. A, 2001, vol. 302, pp. 227-34.

10. Z. Luo, Y. Song, and S. Zhang: Metall. Mater. Trans. A, 2012, vol. 43A, pp. 281-93.

11. B. Lee and S. Kang: Mater. Chem. Phys., 2001, vol. 67, pp. 249-25.

12. I. Ibrahim, F. Mohamed, and E. Lavernia: J. Mater. Sci., 1991, vol. 26 (5), pp. 1137-56.

13. S. Ray: J. Mater. Sci., 1993, vol. 28 (20), pp. 5397-13.

14. N. Barekar, S. Tzamtis, B. Dhindaw, J. Patel, H. Nadendla, and Z. Fan: J. Mater. Eng. Perform., 2009, vol. 18, pp. 1230-40.

15. N. Aniban, R. Pillai, and B. Pai: Mater. Des., 2002, vol. 23, pp. 553-56.

16. N. Harnby, M. Edward, and A. Nienow: Mixing in the Process Industries, 2nd ed., Butterworths-Heinemann Ltd., Oxford, 1985, p. 106.

17. J. Curtis and R. Mcintosh: Ecology, 1950, vol. 31, pp. 434-55.

18. H. Nadendla, Z. Fan, and D. Eskin: TMS2013 Annual Meeting Supplemental Proceedings, pp. 1037-44.

19. G. Eskin and D. Eskin: Ultrasonic Treatment of Light Alloys Melts, Gordon and Breach, ISBN 905699042X, 1998.

20. S. Liu, Y. Chen, and H. Han: J. Alloys Compd., 2009, vol. 624, pp. 266-269.

21. P. Karnezis, G. Durrant, and B. Cantor: Mater. Charact., 1998, vol. 40 (2), pp. 97-109.

22. J. Lewandowski, C. Liu, and W. Hunt: Mater. Sci. Eng. A, 1989, vol. 107 , pp. $241-255$.

23. I. Stone and P. Tsakiropoulos: Mater. Sci. Technol., 1995, vol. 11 (3), pp. 222-227.

24. W. Spitzig, J. Kelly, and O. Richmond: Metallography, 1985, vol. 18 (3), pp. 235-261.

25. A. Rogers and N. Gomar: Geogr. Anal., 1969, vol. 1 (4), pp. 370-384.

26. A. Rogers: Statistical Analysis of Spatial Dispersion: The Quadrat Method, 3rd Ed., vol. 6. Pion, London, 1974, pp. 1-164.

27. J. Wang, Y. Zhou, T. Liao, and Z. Lin: Appl. Phys. Lett., 2006, vol. 89, pp. 0219171-0219173.

28. B. Bramfitt: Metall. Trans., 1970, vol. 1, pp. 1987-95. 